\title{
Pharmacokinetics of ceftiofur in healthy and lipopolysaccharide-induced endotoxemic newborn calves treated with single and combined therapy
}

\author{
Feray ALTAN ${ }^{1) *}$, Kamil UNEY'), Ayse ER ${ }^{2)}$, Gul CETIN ${ }^{3)}$, Burak DIK ${ }^{2)}$, Enver YAZAR ${ }^{2)}$ \\ and Muammer ELMAS ${ }^{2)}$ \\ ${ }^{1)}$ Department of Pharmacology and Toxicology, Faculty of Veterinary Medicine, University of Dicle, Diyarbakir \\ 21280, Turkey \\ ${ }^{2)}$ Department of Pharmacology and Toxicology, Faculty of Veterinary Medicine, University of Selcuk, Konya \\ 42031, Turkey \\ 3)Department of Biochemistry, Faculty of Pharmacy, University of Erzincan, 24100, Turkey
}

J. Vet. Med. Sci.

79(7): 1245-1252, 2017

doi: 10.1292/jvms.16-0641

Received: 21 December 2016 Accepted: 15 May 2017

Published online in J-STAGE: 5 June 2017
ABSTRACT. The aim of this research was to compare plasma pharmacokinetics of ceftiofur sodium (CS) in healthy calves, and in calves with experimentally induced endotoxemia. Six calves received CS $(2.2 \mathrm{mg} / \mathrm{kg}, \mathrm{IM}) 2 \mathrm{hr}$ after intravenous administration of $0.9 \% \mathrm{NaCl}$ (Ceft group). After a washout period, the same 6 calves received CS $2 \mathrm{hr}$ after intravenous injection of lipopolysaccharide (LPS+Ceft group). Another group of 6 calves received a combination of drug therapies that included CS $2 \mathrm{hr}$ after administration of $0.9 \% \mathrm{NaCl}$ (Comb group). A third group of 6 calves received the same combination therapy regimen $2 \mathrm{hr}$ after intravenous injection of lipopolysaccharide (LPS+Comb group). Plasma concentrations of CS and all desfuroylceftiofurrelated metabolites were determined using HPLC, and its pharmacokinetic properties were determined based on a two-compartment model. The peak concentration of CS in the LPS+Comb group occurred the earliest, and the clearance rate of CS was the highest in the Comb and LPS+Comb groups $(P<0.05)$. The elimination half-life of CS in the LPS+Ceft group was longer than that in the Ceft and Comb groups $(P<0.05)$. The results of this study indicate that combined therapies and endotoxemic status may alter the plasma pharmacokinetics of CS in calves.

KEY WORDS: calve, ceftiofur, endotoxemia, pharmacokinetic

Neonatal calf diarrhea is one of the main causes of mortality in calves. Diarrhea is triggered by lipopolysaccharide (LPS) produced by Escherichia coli (E. coli). Exposed calves can exhibit sepsis-related symptoms. The primary aims in treating sepsis in calves should be controlling infection, regulating the inflammatory response, replacing fluids, managing circulatory tension and relieving stress $[1,4,5,41]$.

Ceftiofur sodium (CS) is a broad-spectrum, third-generation cephalosporin that was developed for use in animals, and is the most widely recommended parenteral antibiotic for treatment of $E$. coli-induced diarrhea in calves [4, 5, 53]. CS is approved for the treatment of respiratory infections in cattle and pigs [14]. Although previous studies have shown that $2.2 \mathrm{mg} / \mathrm{kg}$ of CS is effective in animals, this dosage has not been approved for use in preruminating calves [4]. However, CS can be used for extralabel purposes. Pharmacokinetic studies of CS indicate that it is rapidly absorbed the site of the injection, and is distributed throughout the body fluid compartments $[2,48]$. CS is rapidly metabolized to desfuroylceftiofur (DFC) after administration. DFC, which contains an intact $\beta$-lactam ring, is the microbiologically active metabolite of CS [39].

Intravenous administration of LPS can experimentally induce symptoms similar to naturally occurring endotoxemia in animal models of septic shock $[6,54]$. The use of intravenous LPS injections in experimental studies is useful for determining dosage regimens of therapeutic drugs for septic shock $[12,13]$. Although previous studies have described the pharmacokinetics of various antibiotics for treatment of sepsis and septic shock in humans and in veterinary medicine [13,38], the pharmacokinetics of CS in subjects with sepsis or septic shock have not been fully characterized.

In critically ill patients, the distribution of hydrophilic antibiotics including $\beta$-lactams can broaden, and the pharmacokinetic

*Correspondence to: Altan, F., Department of Pharmacology and Toxicology, Faculty of Veterinary Medicine, University of Dicle, Diyarbakir 21280, Turkey. e-mail: feray.altan@dicle.edu.tr

@2017 The Japanese Society of Veterinary Science

This is an open-access article distributed under the terms of the Creative Commons Attribution Non-Commercial No Derivatives (by-nc-nd) License. (CC-BY-NC-ND 4.0: https://creativecommons.org/licenses/by-nc-nd/4.o/) 
profiles of drugs can become unpredictable, requiring careful consideration of pharmacokinetic parameters when determining the dosage of $\beta$-lactam antibiotics [27, 35]. Animal experiments indicate that efficacies of $\beta$-lactams for treatment of systemic microbial infections are related to the duration a drug concentration remains above the minimum inhibitory concentration ( $\mathrm{T}$ $>$ MIC), and time-dependent killing is characteristic of $\beta$-lactams [29]. Although therapeutic drug level monitoring (TDM) methods are not frequently used for $\beta$-lactam treatments, TDM can be used to optimize the dosage of drugs, improve clinical outcomes, and prevent the development of antibiotic resistance when treating critically ill patients for sepsis or other systemic microbial infections requiring a high MIC (minimum inhibition concentration) [37, 44].

The basic aim of the current study was to determine the pharmacokinetic profile of CS with or without combined treatment in endotoxemic calves. We used LPS to experimentally induce endotoxemia in our calf model of septic shock, and monitored the pharmacokinetic parameters of CS and the improvements in clinical and physiological measures that occurred in endotoxemic calves treated with CS alone or CS combined with a vasoactive medication (dopamine), an anti-inflammatory drug (dexamethasone), or intense fluid replacement.

\section{MATERIALS AND METHODS}

\section{Animals and materials}

Eighteen healthy Holstein calves ( $<6$ days old, $43.54 \pm 5.21 \mathrm{~kg}$ ) were used and experimental procedures were approved by the Ethics Committee of the Faculty of Veterinary Medicine at Selcuk University (Konya, Turkey). The animals were divided into two categories, with each category consisting of two groups.

The calves $(n=6)$ in the first group of the first category received $2.2 \mathrm{mg} / \mathrm{kg}$ (IM) dose of CS (Excenel enj, Pfizer ${ }^{\circledR}$, Istanbul, Turkey) $2 \mathrm{hr}$ after administration of a 30-min intravenous infusion of $0.9 \% \mathrm{NaCl}$ (Ceft group). After a 5-day washout period, the calves $(\mathrm{n}=6)$ in the first group of the first category (cross-over design) were treated with CS (2.2 mg/kg, IM) $2 \mathrm{hr}$ after administration of a 30-min intravenous infusion of $2 \mu \mathrm{g} / \mathrm{kg}$ of LPS (E. coli 0111:B4, Sigma-Aldrich, Hamburg, Germany) dissolved in $100 \mathrm{ml} 0.9 \% \mathrm{NaCl}$ (LPS+Ceft group).

The calves in the first group $(\mathrm{n}=6)$ of the second category (parallel design) received combination drug therapy containing [Voluven (20 $\mathrm{ml} / \mathrm{kg}$, IV infusion), ringers lactate $(20 \mathrm{ml} / \mathrm{kg}$, IV), dexamethasone (10 mg/calf, IV), dopamine (30 $\mu \mathrm{g} / \mathrm{kg} / \mathrm{min}, \mathrm{IV})$, sodium bicarbonate $(8.4 \%$, IV), dextrose $(5 \%, \mathrm{IV})]$ and CS $(2.2 \mathrm{mg} / \mathrm{kg}$, IM) $2 \mathrm{hr}$ after administration of a 30-min intravenous infusion of $0.9 \% \mathrm{NaCl}$ (Comb group). The calves in the second group $(\mathrm{n}=6)$ of the second category received the same treatment as the Comb group $2 \mathrm{hr}$ after intravenous injection of $2 \mu \mathrm{g} / \mathrm{kg}$ of LPS (LPS + Comb group).

\section{Parameters of endotoxemia model}

Body temperature is a critical indicator of septic shock. The body temperature of the calves was measured rectally at $0.5,1,1.5$ and $2 \mathrm{hr}$ before and $0,0.5,1,2,4,6,8,10$ and $22 \mathrm{hr}$ after administration of CS. Clinical and physiological indicators, including sucking reflex, capillary refill time, defecation interval, respiratory pattern, arterial blood pressure (auricular artery), heart rate (brachial artery), respiratory rate, and body temperature were monitored and recorded at all time points. The physiological parameters were measured using a BM5Vet Monitor (Bionet, Seoul, South Korea). Changes in the parameters observed were scored numerically.

\section{Sample collection}

The body temperature of the calves was measured rectally at $0.5,1,1.5$ and $2 \mathrm{hr}$ before and $0,0.5,1,2,4,6,8,10 \mathrm{and} 22 \mathrm{hr}$ after the administration of CS. Other clinical and physiological indicators were recorded (Table 1). Physiological parameters were measured using a monitor (BM5Vet Monitor). Changes in parameters were scored numerically. Prior to drug administration, a jugular catheter was inserted into the jugular vein. Blood samples $(4 \mathrm{~m} l)$ were collected from the jugular vein in lithium heparin vacuum tubes at 5, 10, 20, 30, 45, 60 and 90 min before and 2, 3, 4, 6, 8, 10, 22, 34 and 46 hr after administration of CS. Blood samples were centrifuged at $3,000 \mathrm{~g}$ for $10 \mathrm{~min}$ to obtain plasma, and plasma samples were stored at $-70^{\circ} \mathrm{C}$.

Table 1. HPLC-UV double gradient elution scheme

\begin{tabular}{cccc}
\hline $\begin{array}{c}\text { Time } \\
(\mathrm{min})\end{array}$ & $\begin{array}{c}\text { Flow rate } \\
(\mathrm{m} / / \mathrm{min})\end{array}$ & $\begin{array}{c}\mathrm{A} \\
(\%)\end{array}$ & $\begin{array}{c}\mathrm{B} \\
(\%)\end{array}$ \\
\hline 0.01 & 0.3 & 10 & 90 \\
4 & 0.3 & 30 & 70 \\
6 & 0.3 & 25 & 75 \\
8 & 0.3 & 25 & 75 \\
11 & 0.3 & 18 & 82 \\
16 & 0.3 & 10 & 90 \\
20 & 0.3 & 10 & 90 \\
\hline
\end{tabular}

A, acetonitrile; $\mathrm{B}, 0.1 \%$ formic acid in water. 


\section{CS and desfuroylceftiofur-related metabolite analysis}

$\mathrm{CS}$ and all desfuroylceftiofur-related metabolites (DFC) in plasma samples were quantitated using high-pressure liquid chromatography-ultraviolet (HPLC-UV) spectrophotometry (Shimadzu, Tokyo, Japan). The HPLC system consisted of a lowpressure-gradient flow control valve (FCV-10AL), pump (LC-10AD), system control module (CBM 20A), degasser (DGU-14A), auto sampler (SIL-10AD), column oven (CTO-10A), and UV-VIS detector (SPD-10A). Separation was achieved using a PLRP-S column $(150 \times 2.1 \mathrm{~mm}$; internal diameter, $3 \mu \mathrm{m}$; Agilent technologies). The mobile phase, which consisted of acetonitrile (Merck, Darmstadt, Germany) (A) in water (B) with $0.1 \%$ formic acid (Merck), was filtered through a $0.4-\mu \mathrm{m}$ nylon filter $(0.45 \mu \mathrm{m}$, Millipore, Bedford, MA, U.S.A.), and sonicated (Elma, Singen, Germany) for $30 \mathrm{~min}$. A gradient elution was performed using a flow rate of $0.3 \mathrm{ml} / \mathrm{min}$ and an injection volume of $20 \mu \mathrm{l}$ (Table 1). The column oven was set at $40^{\circ} \mathrm{C}$, and the eluate was scanned at $266 \mathrm{~nm}$ for peak detection. The retention time was approximately $11 \mathrm{~min}$, and the total analysis time was $20 \mathrm{~min}$.

CS and DFC were quantitated according to a previously published method [50]. After administration of CS, it is rapidly converted to the biologically active metabolite, DFC. Therefore, plasma DFC concentrations were determined for the pharmacokinetics of CS. In this method, CS is extracted from plasma samples using a derivitization method that converts CS and all metabolites to DFC. In brief, about $200 \mu l$ of each plasma sample was brought to room temperature and transferred to $2 \mathrm{~m} l$ microcentrifuge tubes. Two-hundred microliters of methanol was added, and samples were vortexed for 30 sec. After centrifugation of the sample at $13,000 \mathrm{~g}$ for $10 \mathrm{~min}$ at $22^{\circ} \mathrm{C}$, clear supernatant was transferred to $2 \mathrm{ml}$ microcentrifuge tubes, $100 \mu \mathrm{l}$ of $10 \%$ dithioerythritol in borate buffer was added to each tube, and each tube was placed in a water bath at $50^{\circ} \mathrm{C}$ for $15 \mathrm{~min}$. Tubes were moved from the water bath and allowed to reach room temperature. Next, $100 \mu l$ of $23.3 \%$ iodoacetamide in phosphate buffer was added to each tube, tubes were wrapped in aluminum foil and shaken at $350 \mathrm{rpm}$ for $45 \mathrm{~min}$ at room temperature. Twenty-five microliters of formic acid was added to each sample. Following derivatization, samples were vortexed for 30 sec after stirring at $22^{\circ} \mathrm{C}$, and were centrifuged for $10 \mathrm{~min}$ at $13,000 \mathrm{rpm}$. An aliquot of the resulting supernatant $(20 \mu l)$ was injected into the HPLCUV system. All chemicals and solvents used in our experiments were HPLC-grade.

The CS standards were prepared from a $1 \mathrm{mg} / \mathrm{m} l$ stock solution of CS by diluting 0.05 and $20 \mu \mathrm{g} / \mathrm{m} l$ solutions of CS with 190 and $10 \mu l$ of water, respectively. The assay was linear over the concentration range of 0.05 to $20 \mu \mathrm{g} / \mathrm{ml}$. The limits of quantification (LOQ) and detection (LOD) of the method were found to be 0.1 and $0.05 \mu \mathrm{g} / \mathrm{m} l$ in plasma, respectively. LOD was defined as the lowest amount of analyte detectable in the plasma at which the signal/noise ratio in a sample is at least 3 . LOQ is defined as the lowest computable concentration of the analyte in the plasma with a signal/noise ratio of at least 10 . Intraday percent coefficients of variation (CV) ( $\mathrm{n}=18)$ were as follows: $0.5 \mu \mathrm{g} / \mathrm{ml}, 3.63 \% ; 2 \mu \mathrm{g} / \mathrm{ml}, 2.81 \% ; 10 \mu \mathrm{g} / \mathrm{m} l, 10.05 \%$. Interday per cent CV for CS in plasma ( $\mathrm{n}=54$ ) were as follows: $0.5 \mu \mathrm{g} / \mathrm{ml}, 4.36 \% ; 2 \mu \mathrm{g} / \mathrm{ml}, 1.70 \% ; 10 \mu \mathrm{g} / \mathrm{ml}, 5.93 \%$. The coefficient of variation was calculated as $\mathrm{CV}(\%)=($ standard deviation $/$ mean $) \times 100$.

\section{Data processing}

The plasma concentration-time curve was constructed for each calf using the software program (Phoenix WinNonLin 6.3, Pharsight, St. Louis, MO, U.S.A.). Individual plasma concentration-time curves and Akaike Information Criteria (AIC) were examined for evaluation of the pharmacokinetics of CS and DCF, as previously described [52]. The pharmacokinetic variables were analyzed based on a two-compartment model. The peak plasma concentration $\left(\mathrm{C}_{\max }\right)$, and time elapsed to reach peak plasma concentration $\left(\mathrm{T}_{\max }\right)$ were determined based on the plasma concentration-time curve for each calf. Other parameters were calculated using the pharmacokinetic software program (Phoenix WinNonLin 6.3, Pharsight).

\section{Statistical analysis}

The statistical differences among parameters were determined using SPSS, version 19.0, software. Differences in body temperature were assessed using analysis of variance (ANOVA) and Tukey tests. The mean harmonic value was calculated for the time parameters $\left(t_{1 / 2 a}, t_{1 / 2 \alpha}\right.$ and $\left.t_{1 / 2 \beta}\right)$, which compared using the Mann-Whitney $U$ test. Differences among the other parameters were evaluated using ANOVA and Tukey tests (SPSS 22.0). $P<0.05$ was accepted to represent statistical significance.

\section{RESULTS}

\section{Parameters of endotoxemia model}

The sucking reflex, respiratory activity and general health indicators of the animals changed significantly following treatment with LPS, with signs of septic shock detectable within $1 \mathrm{hr}$ following LPS-induction. However, the calves had recovered from these pathophysiological changes by the last time point post LPS-induction. Following LPS treatment, capillary refill time increased, defecation interval decreased, and each animal's overall condition markedly deteriorated. Irregular decreases in arterial blood pressure and erratic changes in pulse were observed in the LPS+Ceft group. Irregular increases in body temperature and respiration rate were observed in calves treated with LPS (Table 2).

\section{Pharmacokinetics}

Figure 1 illustrates the plasma concentration-time curves of each group. Pharmacokinetic properties were calculated based on a two-compartment model. The pharmacokinetic parameters of CS and DFC are given in Table 3. A lower $\mathrm{C}_{\max } \mathrm{was}_{\mathrm{s}}$ observed $(P<0.05)$ in the LPS + Comb group than in the Ceft and LPS + Ceft groups; $\mathrm{K}_{\mathrm{a}}$ and $\mathrm{t}_{1 / 2 \mathrm{a}}$ of the Comb group were statistically different $(P<0.05)$ from those of the LPS treated groups and all other groups, respectively. The $\mathrm{t}_{1 / 2 \beta}$ of the LPS + Ceft group was longer 
Table 2. General clinical data for healthy calves and experimentally induced endotoxemic calves that received ceftiofur sodium treatment or combination therapy

\begin{tabular}{llllll}
\hline & \multicolumn{1}{c}{ Variables } & Ceft & \multicolumn{1}{c}{ LPS + Ceft } & Comb & \multicolumn{1}{c}{ LPS+Comb } \\
\hline Clinical scoring $^{\text {a) }}$ & Sucking reflex & Normal & No & Normal & Improvement \\
& Capillary refill & Normal & Cyanotic & Normal & Altered light \\
& Defecation interval & Normal & Short & Normal & Normal \\
& Respiration type & Normal & Changed & Normal & Altered light \\
& General health condition & Normal & Changed & Normal & Altered light \\
\hline Monitoringa) & Arterial blood & Normal & Irregular reduction & Normal & Normal \\
& Pressures pulses & Normal & Irregular promotion & Normal & Irregular promotion \\
& Body temperature & Normal & Irregular promotion & Normal & Irregular promotion \\
& Respiratory rate & Normal & Irregular promotion & Normal & Irregular promotion \\
\hline
\end{tabular}

a) General group assessment was performed based on the results of the statistical analysis.

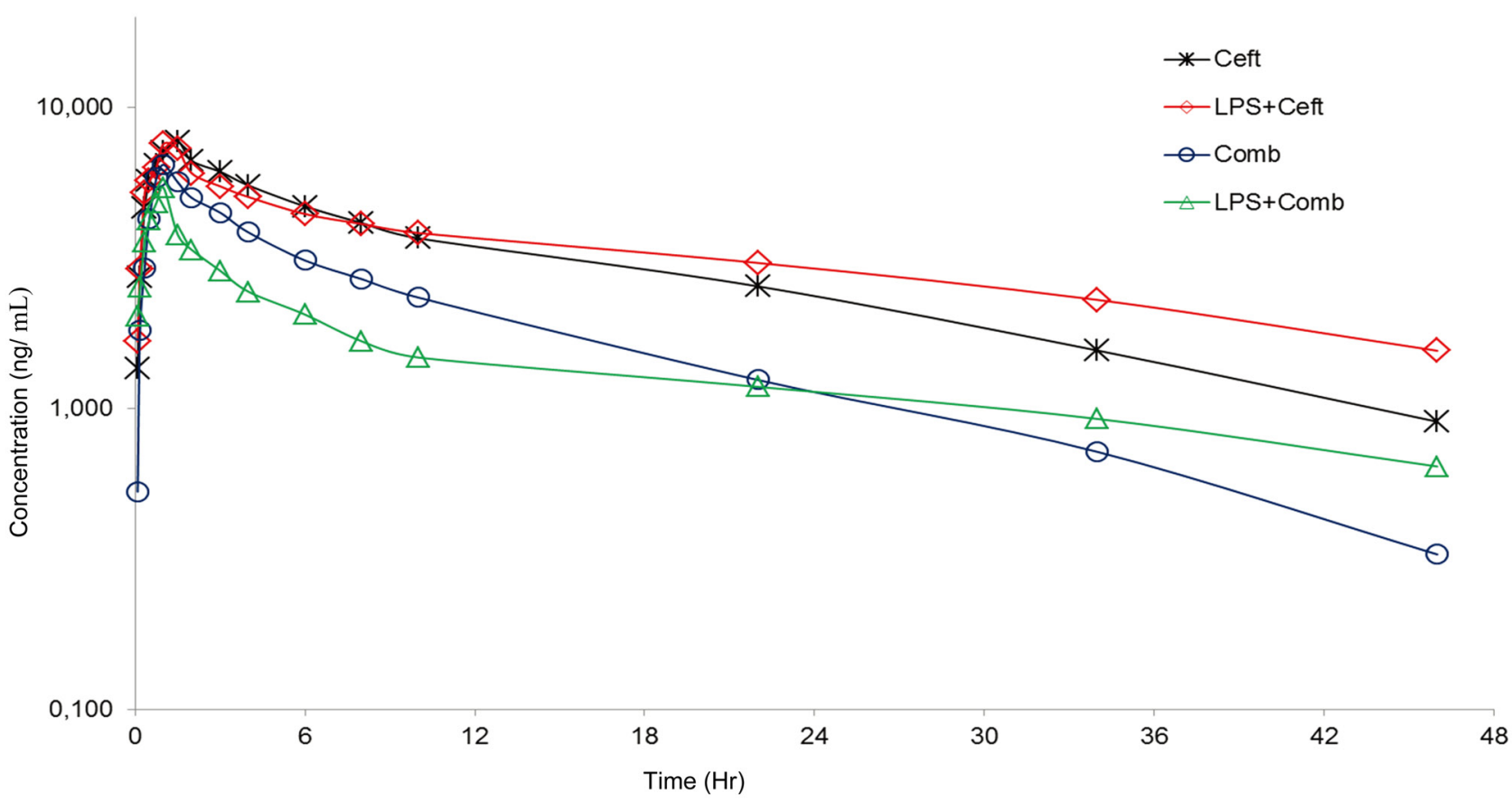

Fig. 1. Semilogarithmic plots of mean plasma concentrations of ceftiofur and desfuroylceftiofur versus time after intramuscular administration of ceftiofur sodium $(2.2 \mathrm{mg} / \mathrm{kg}$ ) in healthy calves (ceftiofur and combined treatment) and experimentally induced endotoxemic calves (Lipopolysaccharide+ceftiofur and Lipopolysaccharide+combined treatment).

$(P<0.05)$ than that of the Ceft and Comb groups, while the CL/F values of the Comb and LPS+Comb groups were larger $(P<0.05)$.

\section{Pharmacodynamics}

Bacterial isolates having an MIC value $<2.0 \mu \mathrm{g} / \mathrm{m} l$ are considered sensitive to CS according to current CLSI guidelines (National Committee for Clinical Laboratory Standards, 1999).

\section{DISCUSSION}

\section{Parameters of the endotoxemia model}

Neonatal calf diarrhea is an important health problem in calves. In the current research, the calves in LPS-treated groups showed some of the clinical and physiological signs of endotoxemia (Table 1). Previous studies have shown that intravenous injection of $E$. coli toxin in calves leads to changes in sucking reflex, capillary refilling time, body temperature, respiration rate, and heart rate [23, 43]. In our current study, a combination therapy initiated $2 \mathrm{hr}$ after LPS injection prevented frequent defecation, and decreased the adverse effects of endotoxemia on capillary refilling time, sucking reflex and general health indicators. Our results are consistent with those obtained in other studies of the treatment of sepsis in calves using various therapeutic agents [4, 28]. Similar results have been reported in previous studies $[1,6]$. These results indicate that LPS treatment can mimic endotoxemia. 
Table 3. Pharmacokinetic parameters of desfuroylceftiofur after ceftiofur sodium injection single dose $(2.2 \mathrm{mg} / \mathrm{kg}, \mathrm{IM})$ in healthy calves and experimentally induced endotoxemic calves

\begin{tabular}{|c|c|c|c|c|}
\hline Parameters & Ceft & $\mathrm{LPS}+\mathrm{Ceft}$ & Comb & LPS +Comb \\
\hline $\mathrm{K}_{\mathrm{a}}(1 / \mathrm{hr})$ & $1.86 \pm 0.45^{\mathrm{ab})}$ & $2.18 \pm 0.66^{\mathrm{a})}$ & $1.21 \pm 0.25^{\mathrm{b})}$ & $2.52 \pm 0.78^{\mathrm{a})}$ \\
\hline $\mathrm{t}_{1 / 2 \mathrm{a}}(\mathrm{hr})(\mathrm{HM})$ & $0.37 \pm 0.09^{b)}$ & $\left.0.32 \pm 0.17^{b}\right)$ & $0.57 \pm 0.12^{\mathrm{a})}$ & $0.27 \pm 0.10^{\mathrm{b})}$ \\
\hline $\mathrm{T}_{\max }(\mathrm{hr})$ & $1.5^{\mathrm{a})}$ & $1.5^{\mathrm{a})}$ & $1^{b)}$ & $1^{b)}$ \\
\hline (Interval) & (1.5) & $(1-1.5)$ & $(1-1.5)$ & $(0.75-1)$ \\
\hline $\mathrm{C}_{\max }(\mu \mathrm{g} / \mathrm{m} l)$ & $7.73 \pm 0.81^{a)}$ & $7.86 \pm 0.98^{\mathrm{a})}$ & $6.54 \pm 0.85^{\mathrm{ab})}$ & $5.74 \pm 1.47^{\mathrm{b})}$ \\
\hline $\operatorname{AUC}_{0-\infty}(\mathrm{hr} * \mu \mathrm{g} / \mathrm{m} l)$ & $153 \pm 26^{\mathrm{b})}$ & $223 \pm 41^{\mathrm{a})}$ & $100 \pm 17^{c)}$ & $\left.86 \pm 17^{c}\right)$ \\
\hline$\alpha(1 / \mathrm{hr})$ & $0.59 \pm 0.32$ & $0.70 \pm 0.48$ & $0.98 \pm 0.21$ & $1.19 \pm 0.59$ \\
\hline $\mathrm{t}_{1 / 2 \alpha}(\mathrm{hr})(\mathrm{HM})$ & $1.17 \pm 1.26$ & $0.99 \pm 0.69$ & $0.71 \pm 0.16$ & $0.58 \pm 0.48$ \\
\hline $\mathrm{V} 1 / \mathrm{F}(\mathrm{m} l / \mathrm{kg})$ & $212 \pm 22^{\mathrm{ab})}$ & $220 \pm 56^{\mathrm{ab})}$ & $189 \pm 36^{\mathrm{b})}$ & $281 \pm 75^{a)}$ \\
\hline $\mathrm{V} 2 / \mathrm{F}(\mathrm{ml} / \mathrm{kg})$ & $182 \pm 64^{\mathrm{b})}$ & $254 \pm 168^{b)}$ & $342 \pm 97^{b)}$ & $568 \pm 126^{a)}$ \\
\hline $\mathrm{K}_{10}(1 / \mathrm{hr})$ & $\left.0.07 \pm 0.01^{b c}\right)$ & $0.05 \pm 0.02^{\mathrm{c})}$ & $0.12 \pm 0.03^{\mathrm{a})}$ & $0.10 \pm 0.03^{\mathrm{ab})}$ \\
\hline $\mathrm{K}_{12}(1 / \mathrm{hr})$ & $0.26 \pm 0.17^{\mathrm{b})}$ & $0.38 \pm 0.31^{\mathrm{ab})}$ & $0.56 \pm 0.11^{\mathrm{ab})}$ & $0.77 \pm 0.41^{\mathrm{a})}$ \\
\hline $\mathrm{K}_{21}(1 / \mathrm{hr})$ & $0.30 \pm 0.16$ & $0.30 \pm 0.18$ & $0.34 \pm 0.14$ & $0.36 \pm 0.18$ \\
\hline$\beta(1 / \mathrm{hr})$ & $0.04 \pm 0.01^{\mathrm{a})}$ & $0.02 \pm 0.00^{\mathrm{b})}$ & $0.04 \pm 0.01^{\mathrm{a})}$ & $0.03 \pm 0.01^{\mathrm{ab})}$ \\
\hline $\mathrm{t}_{1 / 2 \beta}(\mathrm{hr})(\mathrm{HM})$ & $19.90 \pm 3.46^{\mathrm{b})}$ & $32.56 \pm 6.11^{\mathrm{a})}$ & $17.90 \pm 2.54^{b)}$ & $23.39 \pm 5.88^{\mathrm{ab})}$ \\
\hline $\mathrm{CL} / \mathrm{F}(\mathrm{m} l / \mathrm{hr} / \mathrm{kg})$ & $14.70 \pm 2.57^{\mathrm{b})}$ & $10.16 \pm 2.24^{\mathrm{b})}$ & $22.52 \pm 4.19^{\mathrm{a})}$ & $26.68 \pm 7.81^{\mathrm{a})}$ \\
\hline $\mathrm{K}_{12} / \mathrm{K}_{21}$ & $0.86 \pm 0.31^{\mathrm{b})}$ & $1.25 \pm 0.92^{\mathrm{ab})}$ & $1.84 \pm 0.55^{\mathrm{ab})}$ & $2.12 \pm 0.69^{\mathrm{a})}$ \\
\hline $\mathrm{V} 1 / \mathrm{F}+\mathrm{V} 2 / \mathrm{F}(\mathrm{ml} / \mathrm{kg})$ & $394 \pm 67^{b)}$ & $474 \pm 162^{b)}$ & $532 \pm 112^{b)}$ & $850 \pm 169^{\mathrm{a})}$ \\
\hline
\end{tabular}

$\mathrm{a}, \mathrm{b}, \mathrm{c})$ Varied characters in the same row are statistically significantly different $(P<0.05) . \mathrm{K}_{\mathrm{a}}$; absorption rate constant, $\mathrm{t}_{1 / 2 \mathrm{a}}$; absorption half-life, $\mathrm{T}_{\max }$; time to reach the maximum concentration, $\mathrm{C}_{\text {max }}$; peak plasma concentration, AUC; area under curve, $\alpha$; distribution rate constant, $\mathrm{t}_{1 / 2 \alpha}$; distribution half-life, $\mathrm{V} 1 / \mathrm{F}$; central compartment volume of distribution, V2/F; peripheral compartment volume of distribution, $\mathrm{K}_{10}$; elimination rate constant of central compartment, $\mathrm{K}_{12}$; transfer rate constant from central compartment to peripheral compartment, $\mathrm{K}_{21}$; transfer rate constant from peripheral compartment to central compartment, $\beta$; elimination rate constant, $\mathrm{CL} / \mathrm{F}$; total clearance, $\mathrm{t}_{1 / 2 \beta}$; elimination half-life, HM; harmonic means, Ceft; ceftiofur, LPS+Ceft; lipopolysaccharide + ceftiofur, Comb; combined treatments, LPS+Comb; lipopolysaccharide + combined treatments.

\section{Pharmacokinetics/pharmacodynamics}

In vivo, the systemic half-life of ceftiofur is shorter than $10 \mathrm{~min}$ due to rapid degradation of thioester bonds and rapid conversion into DFC, which is the active metabolite in the body. The beta-lactam ring belonging to ceftiofur remains unchanged in DFC [20, 39]. Conversion of ceftiofur to DFC is followed by derivatization, which stabilizes DFC. Therefore, total antibacterial activity related to ceftiofur and its metabolites correlates with DFC concentration in plasma samples.

The definition of a drug-drug interaction (DDI), affecting pharmacokinetics and/or pharmacodynamics, is a change in the effects of one drug induced by the presence of another drug [30]. Drug-drug interactions are more likely to be seen in patients with reduced absorption, disrupted metabolism, renal insufficiency and polymedication [31]. DDIs, which occur in pharmacokinetic stages such as absorption, distribution, metabolism and excretion, are caused by significant changes in pharmacokinetics of drugs $[17,19]$. The liver is the most effective organ at biotransformation of drugs. Drugs metabolized via the liver can be affected by physiological processes such as liver blood flow rate, enzyme activity and binding to proteins [26]. Co-administered drugs have different effects on the activity of drug metabolizing enzymes. In addition, endotoxins produced in response to bacterial inflammatory mediators have different effects on these enzymes [9]. The inhibition or induction of enzymes responsible for chemical modification of drugs indirectly changes the pharmacokinetic profile of the drug [17]. In this study, changes in the pharmacokinetic processes of CS by LPS-induced endotoxicosis and combination treatment may be related to changes in metabolite composition of CS. However, determining the DDI in patients receiving combination drug therapy for LPS may be a very complex task.

In this study, we investigated the pharmacokinetics of intramuscularly administered CS in healthy calves and calves with experimentally induced septic shock (Table 3). The results of our analysis of the pharmacokinetic parameters of CS, as well as those of previous studies performed in healthy calves [2] were consistent with a two-compartment open model (Fig. 1). Pharmacokinetic properties of CS in healthy calves are consistent with Brown et al. [2]. Although the pharmacokinetics of CS have not been described in endotoxemic calves treated with CS alone or in combination therapy, another cephalosporin has been examined in calves [21]. The calves in the LPS $+\mathrm{Comb}$ group have a large CL/F and increased V1/F+V2/F compared to those in the LPS + Ceft group $(P<0.05$, Table 3$)$. These results may indicate that combined therapy alters the pharmacokinetics of CS in endotoxemic calves.

In vivo, ceftiofur is rapidly metabolized to DFC, which is the microbiologically active metabolite of CS [20,39]. In several other studies $[3,10,18,51]$ the dose values of ceftiofur used to calculate pharmacokinetic parameters did not use the total amount of DFC. In this method, conversion of ceftiofur to DFC is followed by derivatization to stabilize DFC. Therefore, total antibacterial activity related to ceftiofur and its metabolites is presented with DFC concentration in plasma samples. In this method, metabolites, including desfuroylceftiofur-protein conjugates, are converted into desfuroylceftiofuracetamide (DCA), which is then quantified 
by HPLC. Therefore, in this study, pharmacokinetic parameters were determined by DFC concentrations in plasma at different time points.

The $\mathrm{K}_{\mathrm{a}}$ in the Comb group was significantly lower than that of the LPS+Ceft and LPS + Comb groups $(P<0.05$; Table 3). The $\mathrm{t}_{1 / 2 \mathrm{a}}$ in the Comb group was significantly longer than that of the other groups $(P<0.05$; Table 3$)$. The $\mathrm{T}_{\max }$ values in the Comb and LPS + Comb groups were significantly shorter $(P<0.05)$, and the $\mathrm{C}_{\max }$ was significantly lower in the LPS + Comb group, compared with that in the other groups $(P<0.05)$. In a previous study, the $\mathrm{t}_{1 / 2 \mathrm{a}}$ of intramuscularly administered oxytetracycline was reduced in calves with experimentally induced endotoxemia [24], and the $t_{1 / 2 a}$ of intramuscularly administered levofloxacin was prolonged, compared with the $t_{1 / 2 a}$ for these drugs in healthy calves [25]. Absorption of CS in the Comb group was significantly slowed, because $\mathrm{K}_{\mathrm{a}}$ was low and $\mathrm{t}_{1 / 2 \mathrm{a}}$ was long. Our current findings suggest that, if CS is to exert its effect rapidly, it should not be administered as a component of combined therapy via a route that involves absorption processes. However, differences in CS absorption processes including $\mathrm{C}_{\max }$ between normal and other groups would not be of particular note.

The V1/F+V2/F in the LPS+Comb was significantly larger than that of the Ceft group $(P<0.05$; Table 3$)$. In addition, the ratio of the rate constants for transfer from the central compartment to peripheral compartments over that for transfer from peripheral compartments to the central compartment $\left(\mathrm{k}_{12} / \mathrm{k}_{21}\right)$ in the LPS +Comb group $(2.12 \pm 0.69)$ was higher than that of the Ceft group $(0.86 \pm 0.31, P<0.05$; Table 3$)$. Recent studies have reported that the distribution volume and the $\mathrm{C}_{\max }$ of meropenem, ceftazidime, cefepime, piperacillin-tazobactam, piperacillin, amikacin, and vancomycin increase and decline respectively in sepsis/septic shock patients receiving fluid therapy and catecholamine in intensive care units (ICU) [7, 42, 46]. Abundant intravenous fluid therapies that increase extracellular compartment fluid may cause a significant increase in distribution [40]. Elevated distribution volumes of CS and cefepime have been shown in experimentally infected pigs and calves [32, 47]. Combination therapies including vasopressor drugs and abundant intravenous fluid therapies may lead to an increase in distribution of CS by causing rapid transfer of the drug into the tissues and prolonging elimination in endotoxemic calves.

In our current study, the Ceft group was used as a control group. We observed that the $t_{1 / 2 \beta}$ in the LPS + Ceft group was significantly longer $(P<0.05)$ than that in the Ceft group, but was similar to that in the Comb and LPS + Comb groups $(P<0.05$, Table 3$)$. In addition, the $t_{1 / 2 \beta}$ in the LPS+Ceft group was significantly longer than in the other groups $(P>0.05)$, and the $C L / F$ in the LPS+Ceft group was meaningfully elevated, compared with that in the other groups $(P>0.05)$. We also found that the CL/F in the Comb and LPS+Comb groups was significantly higher than that of the LPS + Ceft and Ceft groups $(P<0.05$; Table 3). Recent studies have shown that plasma half-life and clearance of CS in experimentally infected pigs were longer than in healthy pigs [47]. A study of septic patients treated with ceftriaxone showed that the clearance time of drug increased when used in combination with hemodynamically active drugs [22]. Also, the clearances of ceftazidime and cefepime were higher in patients with septic shock, compared with those in healthy subjects [34]. Blood pressure is increased by vasopressor drug application and fluid therapy, which are provided to achieve a perfusion pressure and maintain adequate blood flow [8]. Intravenously administered dopamine elevates mean arterial blood pressure of calves by increasing vascular resistance [16]. The use of high-dose dexamethasone has been shown to increase survival rate [15] by reducing oxidative stress and organ damage [54]. These findings indicate that CS was excreted faster in the combination therapy group, whereas in the LPS+Ceft group, the rate of excretion slowed down due to circulatory and renal failures that develop during septic shock and extend the half-life of drugs, particularly those that are excreted by the kidneys. However, the current study indicates that combination drug therapy can help regulate the half-life of CS in endotoxemic calves.

The activity of beta-lactams including CS is characterized by time-dependent killing, and the MIC is an indicator of the potency of an antimicrobial drug against a pathogen [11]. The most useful and predictable parameter for therapeutic efficacy of beta-lactams is the percentage of time its concentration remains above MIC $(\% \mathrm{~T}>\mathrm{MIC})[27,38,49]$. It has been reported that $\% \mathrm{~T}>4 \mathrm{xMIC}$ for maximal bactericidal activity in beta-lactams is shown to be maintained longer $(>100 \%)$ in critically ill patients and patients with compromised immune responses [33, 45]. Bacterial isolates having an MIC value $\leq 2.0 \mu \mathrm{g} / \mathrm{m} l$ are considered sensitive to CS according to current CLSI guidelines (National Committee for Clinical Laboratory Standards, 1999). Based on previous studies, a dose regimen of $6.6 \mathrm{mg} / \mathrm{kg}$ of CS administered subcutaneously is effective for treatment of severe septic disease in neonatal calves and foals according to the MIC $\leq 2.0 \mu \mathrm{g} / \mathrm{ml}$ for $>90 \%$ of the $12-\mathrm{hr}$ study duration [18, 51]. Therefore, the choice of $2.0 \mu \mathrm{g} /$ $\mathrm{m} l$ as the most effective concentration of CS for endotoxemic shock resulting from E. coli appears to be suitable according to current data and CLSI. This pharmacodynamics target was achieved for the major pathogens identified in endotoxemic shock, with effective concentrations of CS observed in plasma for 22, 34, 10 and $6 \mathrm{hr}$ intervals, respectively, in the Ceft, LPS + Ceft, Comb and LPS + Comb groups. In Ceft and LPS + Ceft groups, IM administration of CS at $2.2 \mathrm{mg} / \mathrm{kg}$ reached plasma concentrations $\geq 2.0 \mu \mathrm{g} /$ $\mathrm{ml}$ for $>80 \%$ of the $46 \mathrm{hr}$ study duration, while $\mathrm{T}>\mathrm{MIC}$ above $80 \%$ is not achieved with the $2.2 \mathrm{mg} / \mathrm{kg}$ body weight of CS applied with combined therapy for bacteria with MIC value $\leq 2.0 \mu \mathrm{g} / \mathrm{ml}$ at $46 \mathrm{hr}$ interval (Fig. 1). However, the $\% \mathrm{~T}>\mathrm{MIC}$ is shown to be maintained for $100 \%$ of the dosing interval during treatment of patients in critical condition with septic shock [33, 36]. In this instance, following administration at a dose of $2.2 \mathrm{mg} / \mathrm{kg}$, CS does not maintain a T > MIC above 100\% for bacteria with MIC value $\leq 2.0 \mu \mathrm{g} / \mathrm{m} l$ for a $46 \mathrm{hr}$ interval in Comb and LPS+Comb groups. However, the same dose $(2.2 \mathrm{mg} / \mathrm{kg}$, IM) maintains this target dosage for $34 \mathrm{hr}$ and $6 \mathrm{hr}$ intervals, respectively, in LPS+Ceft and LPS+Comb groups (Fig. 1). The T $>4 \times$ MIC of CS should be sustained across dosing intervals for effective treatment of sepsis in newborn calves. Therefore, the total plasma concentration of CS in this study did not achieve $\% \mathrm{~T}>4 \mathrm{xMIC}$ for bacteria with MIC value $\leq 2.0 \mu \mathrm{g} / \mathrm{m} l$.

In conclusion, the present study indicates that combined therapy may alter the plasma pharmacokinetic of CS in healthy and endotoxemic calves and an experimentally induced model of shock can generate the same types of pathological changes observed during actual disease. The pharmacokinetic data of CS obtained from this study are applicable to the treatment of newborn calves with sepsis. The results of this study suggest that a $2.2 \mathrm{mg} / \mathrm{kg}$ (IM) dose of CS every $6 \mathrm{hr}$ with combined therapy may provide 
plasma concentrations above the therapeutic target of $2.0 \mu \mathrm{g} / \mathrm{ml}$ in endotoxemic new born calves. However, $2.2 \mathrm{mg} / \mathrm{kg}$ (IM) dose of CS could not provide plasma concentrations above the therapeutic target of $2.0 \mu \mathrm{g} / \mathrm{m} l$ in critical patients with septic shock. The dose and dose interval of CS may be increased and reduced in newborn calves with combined therapy and endotoxemic status, respectively. The investigation of pharmacokinetics for farm animals in disease state and undergoing a course of medication may provides a rationale for practical adjustment of established dose regimes.

ACKNOWLEDGMENTS. This manuscript summarizes the PhD thesis of Feray Altan. Research was supported by TUBITAK (110O404). The abstract was submitted to the 12th International Congress of the European Association for Veterinary Pharmacology and Toxicology (EAVPT), Amsterdam, Holland, July 2012.

\section{REFERENCES}

1. Akyuz, E., Coskun, A. and Sen, I. 2016. The effects of fluid resuscitation on the hemodynamic parameters of experimental induced endotoxemia in the neonatal calves. Eurasian J. Vet. Sci. 32: 246-254. [CrossRef]

2. Brown, S. A., Chester, S. T. and Robb, E. J. 1996. Effects of age on the pharmacokinetics of single dose ceftiofur sodium administered intramuscularly or intravenously to cattle. J. Vet. Pharmacol. Ther. 19: 32-38. [Medline] [CrossRef]

3. Brown, S. A., Hanson, B. J., Mignot, A., Millérioux, L., Hamlow, P. J., Hubbard, V. L., Callahan, J. K. and Kausche, F. M. 1999. Comparison of plasma pharmacokinetics and bioavailability of ceftiofur sodium and ceftiofur hydrochloride in pigs after a single intramuscular injection. $J$. Vet. Pharmacol. Ther. 22: 35-40. [Medline] [CrossRef]

4. Constable, P. D. 2004. Antimicrobial use in the treatment of calf diarrhea. J. Vet. Intern. Med. 18: 8-17. [Medline] [CrossRef]

5. Constable, P. D. 2009. Treatment of calf diarrhea: antimicrobial and ancillary treatments. Vet. Clin. North Am. Food Anim. Pract. 25: 101-120, vi. [Medline] [CrossRef]

6. Coskun, A. and Sen, I. 2012. Haematological, biochemical and coagulation changes in calves with endotoxemia. Agric. J. 7: 37-41.

7. Delattre, I. K., Musuamba, F. T., Nyberg, J., Taccone, F. S., Laterre, P. F., Verbeeck, R. K., Jacobs, F. and Wallemacq, P. E. 2010. Population pharmacokinetic modeling and optimal sampling strategy for Bayesian estimation of amikacin exposure in critically ill septic patients. Ther. Drug Monit. 32: 749-756. [Medline] [CrossRef]

8. Dellinger, R. P., Levy, M. M., Carlet, J. M., Bion, J., Parker, M. M., Jaeschke, R., Reinhart, K., Angus, D. C., Brun-Buisson, C., Beale, R., Calandra, T., Dhainaut, J. F., Gerlach, H., Harvey, M., Marini, J. J., Marshall, J., Ranieri, M., Ramsay, G., Sevransky, J., Thompson, B. T., Townsend, S., Vender, J. S., Zimmerman, J. L. and Vincent, J. L. 2008. Surviving Sepsis Campaign: international guidelines for management of severe sepsis and septic shock: 2008. Intensive Care Med. 34: 17-60. [Medline] [CrossRef]

9. Di, L., Feng, B., Goosen, T. C., Lai, Y., Steyn, S. J., Varma, M. V. and Obach, R. S. 2013. A perspective on the prediction of drug pharmacokinetics and disposition in drug research and development. Drug Metab. Dispos. 41: 1975-1993. [Medline] [CrossRef]

10. Doré, E., Angelos, J. A., Rowe, J. D., Carlson, J. L., Wetzlich, S. E., Kieu, H. T. and Tell, L. A. 2011. Pharmacokinetics of ceftiofur crystalline free acid after single subcutaneous administration in lactating and nonlactating domestic goats (Capra aegagrus hircus). J. Vet. Pharmacol. Ther. 34: 25-30. [Medline] [CrossRef]

11. Drusano, G. L. 1998. Infection in the intensive care unit: beta-lactamase-mediated resistance among Enterobacteriaceae and optimal antimicrobial dosing. Clin. Infect. Dis. 27 Suppl 1: S111-S116. [Medline] [CrossRef]

12. Elmas, M., Yazar, E., Uney, K. and Er Karabacak, A. 2006. Influence of Escherichia coli endotoxin-induced endotoxaemia on the pharmacokinetics of enrofloxacin after intravenous administration in rabbits. J. Vet. Med. A Physiol. Pathol. Clin. Med. 53: 410-414. [Medline] [CrossRef]

13. Elmas, M., Yazar, E., Uney, K., Er Karabacak, A. and Traş, B. 2008. Pharmacokinetics of enrofloxacin and flunixin meglumine and interactions between both drugs after intravenous co-administration in healthy and endotoxaemic rabbits. Vet. J. 177: 418-424. [Medline] [CrossRef]

14. EMEA http://www.ema.europa.eu/docs/en_GB/document_library/Maximum_Residue_Limits_-_Report/2009/11/WC500011904.pdf (accessed December 15, 2016)

15. Er, A., Uney, K., Altan, F., Cetin, G., Yazar, E. and Elmas, M. 2009. Effects of different doses of dexamethasone plus flunixin meglumine on survival rate in lethal endotoxemia. Acta Vet. (Beogr.) 59: 47-51. [CrossRef]

16. Greiner, A. S., Skeehan, T. M., Larach, D. R., Schuler, H. G. and Pierce, W. S. 1990. Vascular responses to dopamine and dobutamine in the awake calf during constant aortic flow or constant aortic pressure. J. Cardiovasc. Pharmacol. 15: 392-397. [Medline] [CrossRef]

17. Giacomini, K. M., Huang, S. M., Tweedie, D. J., Benet, L. Z., Brouwer, K. L., Chu, X., Dahlin, A., Evers, R., Fischer, V., Hillgren, K. M., Hoffmaster, K. A., Ishikawa, T., Keppler, D., Kim, R. B., Lee, C. A., Niemi, M., Polli, J. W., Sugiyama, Y., Swaan, P. W., Ware, J. A., Wright, S. H., Yee, S. W., Zamek-Gliszczynski, M. J., Zhang L., International Transporter Consortium 2010. Membrane transporters in drug development. Nat. Rev. Drug Discov. 9: 215-236. [Medline] [CrossRef]

18. Hall, T. L., Tell, L. A., Wetzlich, S. E., McCormick, J. D., Fowler, L. W. and Pusterla, N. 2011. Pharmacokinetics of ceftiofur sodium and ceftiofur crystalline free acid in neonatal foals. J. Vet. Pharmacol. Ther. 34: 403-409. [Medline] [CrossRef]

19. Ito, K., Iwatsubo, T., Kanamitsu, S., Ueda, K., Suzuki, H. and Sugiyama, Y. 1998. Prediction of pharmacokinetic alterations caused by drug-drug interactions: metabolic interaction in the liver. Pharmacol. Rev. 50: 387-412. [Medline]

20. Jacobson, G. A., Martinod, S. and Cunningham, C. P. 2006. Determination of ceftiofur in bovine plasma by HPLC-DAD. J. Pharm. Biomed. Anal. 40: 1249-1252. [Medline] [CrossRef]

21. Joshi, B. and Sharma, S. K. 2009. The pharmacokinetics of cefepime in E. coli lipopolysaccharide induced febrile buffalo calves. Vet. Arh. 79: 523-530.

22. Joynt, G. M., Lipman, J., Gomersall, C. D., Young, R. J., Wong, E. L. and Gin, T. 2001. The pharmacokinetics of once-daily dosing of ceftriaxone in critically ill patients. J. Antimicrob. Chemother. 47: 421-429. [Medline] [CrossRef]

23. Kinsbergen, M., Bruckmaier, R. M. and Blum, J. W. 1994. Metabolic, endocrine and haematological response to intravenous $E$. coli endotoxin administration in 1-week-old calves. J. Vet. Med. A Physiol. Pathol. Clin. Med. 41: 530-547. [CrossRef]

24. Kumar, R. and Malik, J. K. 2001. Effects of multiple injections of Escherichia coli endotoxin on the pharmacokinetics and dosage regimens of a long-acting formulation of oxytetracycline (OTC-LA) in cross-breed calves. Vet. Arh. 71: 245-263.

25. Kumar, S., Kumar, S., Kumar, V., Singh, K. K. and Roy, B. K. 2009. Pharmacokinetic studies of levofloxacin after oral administration in healthy and febrile cow calves. Vet. Res. Commun. 33: 887-893. [Medline] [CrossRef] 
26. Martinez, M. and Modric, S. 2010. Patient variation in veterinary medicine: part I. Influence of altered physiological states. J. Vet. Pharmacol. Ther. 33: 213-226. [Medline] [CrossRef]

27. McKinnon, P. S. and Davis, S. L. 2004. Pharmacokinetic and pharmacodynamic issues in the treatment of bacterial infectious diseases. Eur. J. Clin. Microbiol. Infect. Dis. 23: 271-288. [Medline] [CrossRef]

28. Nagy, D. W. 2009. Resuscitation and critical care of neonatal calves. Vet. Clin. North Am. Food Anim. Pract. 25: 1-11, xi. [Medline] [CrossRef]

29. Nicolau, D. P. 2008. Pharmacodynamic optimization of $\beta$-lactams in the patient care setting. Crit. Care 12 Suppl 4: S2. [Medline] [CrossRef]

30. Palleria, C., Di Paolo, A., Giofrè, C., Caglioti, C., Leuzzi, G., Siniscalchi, A., De Sarro, G. and Gallelli, L. 2013. Pharmacokinetic drug-drug interaction and their implication in clinical management. J. Res. Med. Sci. 18: 601-610. [Medline]

31. Papadopoulos, J. and Smithburger, P. L. 2010. Common drug interactions leading to adverse drug events in the intensive care unit: management and pharmacokinetic considerations. Crit. Care Med. 38 Suppl: S126-S135. [Medline] [CrossRef]

32. Pawar, Y. G. and Sharma, S. K. 2008. Influence of E. coli lipopolysaccharide induced fever on the plasma kinetics of cefepime in cross-bred calves. Vet. Res. Commun. 32: 123-130. [Medline] [CrossRef]

33. Pea, F. and Viale, P. 2009. Bench-to-bedside review: Appropriate antibiotic therapy in severe sepsis and septic shock--does the dose matter? Crit Care 13: 214. [Medline] [CrossRef]

34. Pea, F., Viale, P. and Furlanut, M. 2005. Antimicrobial therapy in critically ill patients: a review of pathophysiological conditions responsible for altered disposition and pharmacokinetic variability. Clin. Pharmacokinet. 44: 1009-1034. [Medline] [CrossRef]

35. Roberts, J. A. and Lipman, J. 2009. Pharmacokinetic issues for antibiotics in the critically ill patient. Crit. Care Med. 37: 840-851, quiz 859. [Medline] [CrossRef]

36. Roberts, J. A., Norris, R., Paterson, D. L. and Martin, J. H. 2012. Therapeutic drug monitoring of antimicrobials. Br. J. Clin. Pharmacol. 73: 27-36. [Medline] [CrossRef]

37. Roberts, J. A., Ulldemolins, M., Roberts, M. S., McWhinney, B., Ungerer, J., Paterson, D. L. and Lipman, J. 2010. Therapeutic drug monitoring of $\beta$-lactams in critically ill patients: proof of concept. Int. J. Antimicrob. Agents 36: 332-339. [Medline] [CrossRef]

38. Roos, J. F., Bulitta, J., Lipman, J. and Kirkpatrick, C. M. 2006. Pharmacokinetic-pharmacodynamic rationale for cefepime dosing regimens in intensive care units. J. Antimicrob. Chemother. 58: 987-993. [Medline] [CrossRef]

39. Salmon, S. A., Watts, J. L. and Yancey, R. J. Jr. 1996. In vitro activity of ceftiofur and its primary metabolite, desfuroylceftiofur, against organisms of veterinary importance. J. Vet. Diagn. Invest. 8: 332-336. [Medline] [CrossRef]

40. Scaglione, F. and Paraboni, L. 2008. Pharmacokinetics/pharmacodynamics of antibacterials in the Intensive Care Unit: setting appropriate dosing regimens. Int. J. Antimicrob. Agents 32: 294-301. [Medline] [CrossRef]

41. Sen, I. and Constable, P. D. 2013. General overview to treatment of strong ion (metabolic) acidosis in neonatal calves with diarrhea. Eurasian J. Vet. Sci 29: 114-120.

42. Seyler, L., Cotton, F., Taccone, F. S., De Backer, D., Macours, P., Vincent, J. L. and Jacobs, F. 2011. Recommended $\beta$-lactam regimens are inadequate in septic patients treated with continuous renal replacement therapy. Crit. Care 15: R137. [Medline] [CrossRef]

43. Singh, D., Bansal, S. K. and Ghumman, G. S. 2011. Effect of flunixin meglumine alone and in combination on haemodynamics during bovine endotoxic shock and after treatment. JBISE 4: 29-33. [CrossRef]

44. Sinnollareddy, M. G., Roberts, M. S., Lipman, J. and Roberts, J. A. 2012. $\beta$-lactam pharmacokinetics and pharmacodynamics in critically ill patients and strategies for dose optimization: a structured review. Clin. Exp. Pharmacol. Physiol. 39: 489-496. [Medline] [CrossRef]

45. Sime, F. B., Roberts, M. S., Peake, S. L., Lipman, J. and Roberts, J. A. 2012. Does beta-lactam pharmacokinetic variability in critically ill patients justify therapeutic drug monitoring? A systematic review. Ann. Intensive Care 2: 35. [Medline] [CrossRef]

46. Taccone, F. S., Laterre, P. F., Spapen, H., Dugernier, T., Delattre, I., Layeux, B., De Backer, D., Wittebole, X., Wallemacq, P., Vincent, J. L. and Jacobs, F. 2010. Revisiting the loading dose of amikacin for patients with severe sepsis and septic shock. Crit. Care 14: R53. [Medline] [CrossRef]

47. Tantituvanont, A., Yimprasert, W., Werawatganone, P. and Nilubol, D. 2009. Pharmacokinetics of ceftiofur hydrochloride in pigs infected with porcine reproductive and respiratory syndrome virus. J. Antimicrob. Chemother. 63: 369-373. [Medline] [CrossRef]

48. Tell, L., Harrenstien, L., Wetzlich, S., Needham, M., Nappier, J., Hoffman, G., Caputo, J. and Craigmill, A. 1998. Pharmacokinetics of ceftiofur sodium in exotic and domestic avian species. J. Vet. Pharmacol. Ther. 21: 85-91. [Medline] [CrossRef]

49. Toutain, P. L., del Castillo, J. R. E. and Bousquet-Mélou, A. 2002. The pharmacokinetic-pharmacodynamic approach to a rational dosage regimen for antibiotics. Res. Vet. Sci. 73: 105-114. [Medline] [CrossRef]

50. Uney, K., Altan, F., Er, A., Yazar, E., Elmas, M. 2011. Determination of an HPLC-UV validation of ceftiofur and its active metabolite desfuroylceftiofur in rabbit plasma and its application to the pharmacokinetic study. SUBAPK: 11401102 (Un published data).

51. Woodrow, J. S., Caldwell, M., Cox, S., Hines, M. and Credille, B. C. 2016. Comparative plasma pharmacokinetics of ceftiofur sodium and ceftiofur crystalline-free acid in neonatal calves. J. Vet. Pharmacol. Ther. 39: 271-276. [Medline] [CrossRef]

52. Yamaoka, K., Nakagawa, T. and Uno, T. 1978. Application of Akaike's information criterion (AIC) in the evaluation of linear pharmacokinetic equations. J. Pharmacokinet. Biopharm. 6: 165-175. [Medline] [CrossRef]

53. Yazar, E. 2016. Chemotherapeutics. pp: 25-198. In: Veterinary Drug, Ed: Yazar E, Olgun-Celik Press, Konya, Turkey.

54. Yazar, E., Er, A., Uney, K., Bulbul, A., Avci, G. E., Elmas, M. and Traş, B. 2010. Effects of drugs used in endotoxic shock on oxidative stress and organ damage markers. Free Radic. Res. 44: 397-402. [Medline] [CrossRef] 